African Crop Science Journal by African Crop Science Society is licensed under a Creative Commons Attribution 3.0 Uganda License. Based on a work at www.ajol.info/ and www.bioline.org.br/cs DOI: http://dx.doi.org/10.4314/acsj.v24i2.8

\title{
HERITABILITY FOR RESISTANCE TO ROSETTE DISEASE IN EXOTIC VALENCIA GROUNDNUTS
}

R.G. NALUGO, W. WAMBI ${ }^{1}$, J.M. SEBBULIBA ${ }^{2}$, D.K. OKELLO ${ }^{3}$ and N. PUPPALA ${ }^{4}$ National Agricultural Research Organization, Rwebitaba Zonal Agricultural Research and Development Institute, P. O. Box 96, Fortportal, Uganda

${ }^{1}$ National Agricultural Research Organization, Bulindi Zonal Agricultural Research and Development Institute, P. O. Box 101, Hoima, Uganda

${ }^{2}$ Department of Agricultural Production, School of Agricultural Sciences, Makerere University, P. O. Box 7062, Kampala, Uganda

${ }^{3}$ National Semi-Arid Resources Research Institute, P. O. Box Private Bag Soroti, Uganda ${ }^{4}$ New Mexico State University - Agricultural Science Center at Clovis, 2346 SR 288, Clovis, New Mexico, USA

Corresponding author: wambiwilber@yahoo.com

(Received 25 March, 2015; accepted 4 April, 2016)

\begin{abstract}
Groundnut rosette disease (GRD) is the most destructive virus disease of Valencia groundnuts (Arachis hypogaea L.) in sub-Saharan Africa. Cultural, biological and chemical control measures have received limited success due to small scale farmers' inability to use them. Use of host plant resistance provides the most effective and economically viable management option for the resource poor farmers. This study was conducted to determine heritability for resistance to GRD in Valencia groundnuts. Six crosses; Valencia C $\left(\mathrm{P}_{1}\right) \times \operatorname{ICGV-SM} 90704\left(\mathrm{P}_{2}\right)$, Valencia C $\left(\mathrm{P}_{1}\right)$ × ICGV-SM 96801 $\left(\mathrm{P}_{2}\right)$, Valencia C $\left(\mathrm{P}_{1}\right) \times$ ICGV-SM $99566\left(\mathrm{P}_{2}\right)$, NuMex-M $\left(\mathrm{P}_{1}\right) \times$ ICGV-SM $90704\left(\mathrm{P}_{2}\right)$, NuMex-M $\mathrm{M}_{3} \times$ ICGV-SM $96801\left(\mathrm{P}_{2}\right)$, and NuMex-M $\mathrm{M}_{3}\left(\mathrm{P}_{1}\right) \times \operatorname{ICGV-SM} 99566\left(\mathrm{P}_{2}\right)$, were made to generate $\mathrm{F}_{1}$, $\mathrm{F}_{2}, \mathrm{BC}_{1} \mathrm{P}_{1}$ and $\mathrm{BC}_{1} \mathrm{P}_{2}$ populations. Data on GRD severity were collected on a 1-9 score scale. Genetic Advance as a percentage of the mean (GAM) and heritability were estimated using variance components. Phenotypic Coefficient of Variation (PCV) and Genotypic Coefficient of Variation (GCV) estimates were high (20.04-70.1\%) in the six crosses, except for Valencia C $\times$ ICGV-SM 96801(18.1\%) and NuMex-M $\times$ ICGV-SM 96801(17.1\%), which exhibited moderate GCV values. Broad and narrow sense heritability estimates for GRD disease score ranged from 64.1 to $73.7 \%$ and 31 to $41.9 \%$, respectively, in all the crosses. GAM was high in all the crosses (2150.7\%), except for Valencia C x ICGV-SM 96801 (14.67), M $_{3}$ ICGV-SM 99566 (18\%) and NuMex-M x ICGVSM $96801(13.5 \%)$ crosses that exhibited moderate GAM. The study revealed the presence of variability of GRD resistance, implying that genetic improvement of these exotic materials is possible.
\end{abstract}

Key Words: Arachis hypogea, coefficients of variation

\section{RÉSUMÉ}

La maladie de rosette chez l'arachide (Arachis hypogaea L.) est la plus destructive des maladies virales chez les variétés Valencia en Afrique au sud du Sahara. Les moyens de lutte culturale, biologique et chimique présentent des limitations surtout liées à l'inhabilité des petits producteurs à les mettre en pratique. L'utilisation de variétés resistantes représente le moyen le plus efficace et économiquement viable pour les petits producteurs. La présente étude a été conduite afin de déterminer l'héritabilité de la résistance à la maladie de rosette chez les variétés d'arachide Valencia. Six croisements; Valencia C $\left(\mathrm{P}_{1}\right) \times \operatorname{ICGV-SM} 90704\left(\mathrm{P}_{2}\right)$, Valencia C $\left(\mathrm{P}_{1}\right) \times \mathrm{ICGV}$ - 
SM 96801 $\left(\mathrm{P}_{2}\right)$, Valencia C $\left(\mathrm{P}_{1}\right) \times$ ICGV-SM $99566\left(\mathrm{P}_{2}\right)$, NuMex-M ${ }_{3}\left(\mathrm{P}_{1}\right) \times \operatorname{ICGV}-\mathrm{SM} 90704\left(\mathrm{P}_{2}\right)$, NuMex-M $\times$ ICGV-SM $96801\left(\mathrm{P}_{2}\right)$, et NuMex-M $\left(\mathrm{P}_{1}\right) \times$ ICGV-SM $99566\left(\mathrm{P}_{2}\right)$, ont été effectués afin de générer $\mathrm{F}_{1}, \mathrm{~F}_{2}$, $\mathrm{BC}_{1} \mathrm{P}_{1}$ et $\mathrm{BC}_{1} \mathrm{P}_{2}$ populations. Des données ont été collectées sur le degré sévérité de GRD en se servant d'une échelle de 1-9. Les paramètres d'avancée génétique exprimée en pourcentage de la moyenne (GAM) et héritabilité ont été estimés à partir de composantes de variance. Le coefficient de variation phénotypique (PCV) et génotypique (GCV) estimés étaient élevés $(20,04-70,1 \%)$ dans les six croisements, sauf pour Valencia $\mathrm{C} \times \mathrm{ICGV-SM}$ 96801(18,1\%) et NuMex-M $\times$ ICGV-SM 96801(17,1\%), où les valeurs de GCV étaient modérées. Les valeurs de l'héritabilité au sens large et au sens strict pour la résistance à GRD variaient respectivement de 64,1 à 73,7\% et de 31 à 41,9\%, au niveau de tous les croisements. Les valeurs de GAM étaient élevées au niveau de tous les croisements (21-50,7\%), sauf pour les croisements Valencia C x ICGV-SM 96801 (14,67), M x ICGV-SM 99566

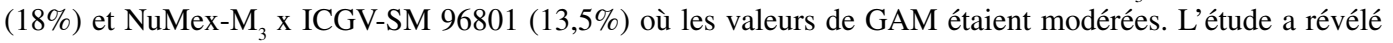
l'existence dans la résistance au GRD, ceci implique qu'il est possible d'entreprendre l'amélioration génétique de ces matériels.

Mots Clés: Arachis hypogea, coefficients de variation

\section{INTRODUCTION}

Valencia groundnuts belong to one of the botanical varieties of cultivated groundnuts (Arachis hypogea L.) (Krapovickas and Gregory, 1994) known for their quality attributes like good and distinctive flavour with a soft skin (Patte $e t$ al., 2001; Mark et al., 2009), early maturity, high number of seeds per pod and relatively bigger seeds that make it key for commercial purposes. Also, they are the most preferred for high oil content (Kaaya and Warren, 2005) compared with other groundnut botanical varieties. Also, they are the most preferred for high oil content (Kaaya and Warren, 2005) compared with other groundnut sub-species. Despite their importance, production is still constrained by the groundnut rosette disease (GRD) in Uganda. The disease is sporadic and unpredictable, and can result in yield losses of up to 100\% (Waliyar, 1999; Subrahmanyam et al., 2001; Adu Dapaah et al., 2004).

There have been efforts to control GRD using a combination of cultural, biological and chemical measures (Waliyar et al., 2007; Okello et al., 2014); however, little success has been achieved because small scale farmers seldom use them. In addition, chemical control of aphids (Aphis craccivora) which transmit the disease is not economically viable because of their persistent nature in the disease transmission (Waliyar et al., 2007). Use of host plant resistance is the most effective and economically viable management options for the resource poor farmers, especially in Uganda. However, it is limited by lack of resistant varieties and information on heritability of GRD resistance on the available Valencia breeding materials.

Estimation of genetic variability with the help of suitable parameters such as genetic coefficients of variation, heritability estimates and genetic advance is absolutely necessary to start an efficient breeding programme (Atta et al., 2008; Janila et al., 2013; Wambi et al., 2014). Kayondo et al. (2014) reported a high (93\%) heritability estimate for GRD rosette disease in Uganda. However, heritability estimates depend on the genetic background of the materials used and the environment from which the populations are evaluated (Kearsey and Pooni, 1996; Wambi, 2014; Wambi et al., 2014).Therefore, this study was conducted to estimate genotypic and phenotypic coefficients of variations, and heritability for GRD resistance, in Valencia groundnut genotypes.

\section{MATERIALS AND METHODS}

Study area. The study was conducted at the National Semi-Arid Resources Research Institute (NaSARRI), of the National Agricultural Research Organisation (NARO), located $01^{\circ}-3000 \mathrm{~N}$ and $33^{\circ} 3300 \mathrm{E}$ in Serere district in Uganda. This is a known hotspot for GRD in the country (Okello $e t$ al., 2010). It receives an annual rainfall of $1,000-$ $1,200 \mathrm{~mm}$. 
The plant materials for this study were developed by crossing two exotic susceptible Valencia lines, Valencia $\mathrm{C}$ and $\mathrm{NuMex}_{3} \mathrm{M}_{3}$ provided by the Plant Breeding Department New Mexico State University, USA; and Rosette resistant lines, namely Serenut 6T (ICGV SM 99566), Serenut 2 (ICGV-SM 90704) and Mali (ICGV-SM 96801), provided by the Groundnut Improvement Programme at the NaSARRI, Uganda.

Six crosses, namely Valencia $\mathrm{C} \times \mathrm{ICGV}-\mathrm{SM}$ 90704, Valencia C × ICGV-SM 96801, Valencia C × 99566, NuMex-M $\times$ ICGV-SM 90704, NuMex-M $\times$ ICGV-SM 96801 and NuMex-M $\times$ × ICGV-SM 99566) were made to generate $\mathrm{F}_{1} \mathrm{~s}$. The $\mathrm{F}_{1} \mathrm{~s}$ of each cross were further crossed to their parents $\mathrm{P}_{1}$ (female parent) and $\mathrm{P}_{2}$ (male parent) to derive $\mathrm{BC}_{1} \mathrm{P}_{1}$ and $\mathrm{BC}_{1} \mathrm{P}_{2}$ generations, respectively. On the same $F_{1}$ plants, $F_{2}$ seed was generated by allowing some flowers to self-pollinate.

The six generations, namely $\mathrm{P}_{1}, \mathrm{P}_{2}, \mathrm{~F}_{1}, \mathrm{~F}_{2}$, $\mathrm{BC}_{1} \mathrm{P}_{1}$ and $\mathrm{BC}_{1} \mathrm{P}_{2}$ of each cross were evaluated in a randomised complete block design (RCBD), with three replications. The materials were planted in six row plots of $3 \mathrm{~m}$ length, at a spacing of $45 \mathrm{~cm}$ x $15 \mathrm{~cm}$. Acholi white, a highly susceptible local variety, was used as the infector line to increase disease pressure, and was planted in a single row between every two rows of test materials. The infector rows were planted 14 days before the test materials.

Data collection. Disease severity data were recorded at 115 days after planting, on ten randomly selected plants in each replicate. Each plant was scored for a rating scale of 1-9 adopted from the Groundnut Improvement Programme at NaSARRI, Serere in Uganda (Okello et al., 2014).

Where:

1-3 represented highly resistant, HR, (where $1=$ resistant with no symptom, 2 = very slight leaf symptoms and $3=$ slight leaf symptoms but still negligible), 4-5 resistant, $R$, with leaf symptoms and no stunting (where $4=$ showed $50 \%$ symptoms on leaves, and $5=$ all leaves showed symptoms of chlorosis), 6-7 moderately susceptible (MS) with leaf symptoms and stunting (where 6 was $25 \%$ stunted and $7=50 \%$ stunted), 8-9 highly susceptible (HS) with severe leaf symptoms with $>50 \%$ stunt (where $8=$ has few pods; while $9=$ no pod at all is expected).

Data analysis. Data on disease severity on individual plants of each generation for each cross were subjected to one way ANOVA, using GenStat Version 13 computer program. ANOVA was based on the linear mathematical model:

$Y i j=\mu+r i+g j+e i j$

Where:

Yij = observed effect for ith replication and jth genotype,

$\mu=$ grand mean of the experiment,

ri $=$ effect of the ith replication,

gi $=$ effect of the jth genotype,

eij $=$ residual effect

Where the ANOVA showed significant differences, the treatment means were separated using by Fisher's protected Least Significant Difference at 5\% probability level (Payne et al., 2010).

Estimation of variance components. Variance components that included, environmental, genotypic, additive and dominance, were obtained following the procedure of Kearsy and Pooni (1996).

$\sigma^{2} \mathrm{e}=\left(\sigma^{2} \mathrm{P}_{1}+\sigma^{2} \mathrm{P}_{2}+2 \sigma^{2} \mathrm{~F}_{1}\right) / 4 \ldots \ldots \ldots \ldots \ldots$ Equation 1

Where: $\sigma^{2} \mathrm{e}=$ Environmental variance or error, $\sigma^{2} P_{1} \sigma^{2} P_{2}$ and $\sigma^{2} F_{1}=$ Variance of susceptible parents, resistant parents and first filial generations, respectively.

Phenotypic variance $=\left[\sigma^{2} F_{2}\right]=$ variance of $F_{2}$ generation ............................ Equation 2

Genotypic variance in $F_{2}\left[\sigma^{2} G\left(F_{2}\right)\right]=\sigma^{2} F_{2}-\sigma^{2} e$ Equation 3

Where:

$\sigma^{2} F_{2}=$ variance of $F_{2}$ generation, and $\sigma^{2} e=$ Environmental variance 
Additive variance in $\left.\mathrm{F}_{2 \Gamma} \sigma^{2} \mathrm{~A}\left(\mathrm{~F}_{2}\right)\right]=\left(2 \sigma^{2} \mathrm{~F}_{2}\right)-\left[\sigma^{2} \mathrm{BC}\right.$ $\left.+\sigma^{2} \mathrm{BC}_{2}\right]$ Equation 4

Where:

$\sigma^{2} \mathrm{~F}_{2}=$ variance of $\mathrm{F}_{2}$ generation, and $\sigma^{2} \mathrm{BC}_{1}$ and $\sigma^{2} \mathrm{BC}_{2}=$ variance of backcross to female and male parents, respectively.

Dominance variance in $\left.\mathrm{F}_{2[} \sigma^{2} \mathrm{D}\left(\mathrm{F}_{2}\right)\right]=\sigma^{2} \mathrm{G}\left(\mathrm{F}_{2}\right)$ $\sigma 2 \mathrm{~A}\left(\mathrm{~F}_{2}\right)$ Equation 5

Where:

$\left[\sigma^{2} \mathrm{G}\left(\mathrm{F}_{2}\right)\right]=$ Genotypic variance in $\mathrm{F}_{2}$, and $\sigma^{2} \mathrm{~A}\left(\mathrm{~F}_{2}\right)$ $=$ Additive variance in $\mathrm{F}_{2}$.

Coefficient of variability. Both the genotypic coefficient of variation (GCV) and phenoptypic coefficient of variation (PCV) were estimated following the method suggested by Singh and Chaudhury (1985), where the GCV and PCV values were classified as low (0-10), medium (1120 ) and high (20 and above) (Sivasubramanian and Menon, 1973).

$\mathrm{PCV}=(\sqrt{ } \mathrm{Vp}) / \mathrm{X} * 100$ Equation 6

$\mathrm{GCV}=(\sqrt{ } \mathrm{VG}) / \mathrm{X} * 100$ Equation 7

Where:

$\mathrm{V}_{\mathrm{P}}=$ Phenotypic variance, $\mathrm{V}_{\mathrm{G}}=$ Genotypic variance, and $\mathrm{X}=$ Grand mean of the character.

Estimation of heritability. The variance components descibed above were used to determine broad sense heritability $\left(h^{2}{ }_{\mathrm{b}}\right)$ and narrow sense heritability $\left(h^{2}\right)$, following Keasey and Pooni(1996) in all the six crosses as detailed below:

$h_{\mathrm{b}}^{2}=100\left[\sigma^{2} \mathrm{G}\left(\mathrm{F}_{2}\right) / \mathrm{V}_{\mathrm{F} 2}\right]$ Equation 8

Where: $h^{2}{ }_{\mathrm{b}}=$ Broad-sense heritability, $\sigma^{2} \mathrm{G}\left(\mathrm{F}_{2}\right)=$ genotypic variance in $\mathrm{F}_{2}$ and $\mathrm{V}_{\mathrm{F} 2}=$ variance of $\mathrm{F}_{2}$ generation

$h^{2} \mathrm{n}=100\left[\sigma^{2} \mathrm{~A}\left(\mathrm{~F}_{2}\right) / \mathrm{V}_{\mathrm{F} 2}\right]$ Equation 9
Where: $h^{2} \mathrm{n}=$ Narrow-sense heritability, $\sigma^{2} \mathrm{~A}\left(\mathrm{~F}_{2}\right)$ $=$ additive variance in $\mathrm{F}_{2}$, and $\mathrm{V}_{\mathrm{F} 2}=$ variance of $\mathrm{F}_{2}$ generation.

Estimation of genetic advance (GA). Genetic advance was estimated following Singh and Chaudhury (1985) method.

Genetic advance $(\mathrm{GA})=h^{2} \times \mathrm{k} \times \sigma^{2}{ }_{\mathrm{p}}$ Equation 10

Where:

$h^{2}{ }_{n}=$ Narrow sense heritability estimate, $\mathrm{s}^{2}{ }_{\mathrm{p}}=$ Phenotypic standard deviation, and $\mathrm{K}=$ Selection intensity at $5 \%$ is equal to 2.06 .

Genetic advance as percent of mean

$(\mathrm{GAM} \%)=(\mathrm{GA} / \mathrm{X}) * 100$

Where:

$\mathrm{X}=$ Grand mean of the trait, and GA = Genetic advance

The Genetic Advance as percent of mean (GAM\%) was categorised as described by Johnson et al. (1955), as low (0-10), medium (1020) and high (21 and above).

\section{RESULTS}

There were significant variations in the generations for disease severity (Table 1). The donor parents, ICGV - SM 99566 and ICGV-SM 90704, were highly resistant with mean scores ranging from 1.33-2.83; while ICGV -SM 96801 was slightly resistant with the score that ranged 4 to 6 . All the susceptible genotypes, Valencia C and NuMex-M $\mathrm{M}_{3}$ exhibited higher disease score that ranged from 7.5 to 8 .

All the six $\mathrm{F}_{1} \mathrm{~s}$ showed high resistance to GRD (mean score range 1.67 to 2.0 ), and the mean disease score in $\mathrm{F}_{2}$ were moderately resistant (Table 1). The segregants of $\mathrm{F}_{2}$ from ICGV-SM 90704 donor line were highly resistant, with mean scores in the range of 2.3-2.73; whereas those from ICGV-SM 96801 were susceptible with mean scores of 5 to 6 . 
Coefficients of variability and heritability. Table 2 shows phenotypic and genotypic coefficients of variation, heritability and GAM estimates for GRD resistance in six crosses. In all crosses, the dominance variance component $\left(\mathrm{V}_{\mathrm{D}}\right)$ exhibited relatively higher magnitudes $(0.65-0.99)$ compared with the additive component $\left(\mathrm{V}_{\mathrm{A}}\right)$, except for

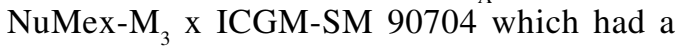
relatively lower (0.37) magnitude. The PCV and GCV estimates were high (20.04-70.1\%) in all the six crosses, except for Valencia $\mathrm{C} \times \mathrm{ICGV}-\mathrm{SM}$ 96801(18.1\%) and NuMex-M $\times$ ICGV-SM

TABLE 1. Groundnut Rosette Disease mean score and standard error for the six generations of the 6 crosses of groundnuts in Eastern Uganda

\begin{tabular}{lcccccc}
\hline Generation & $\begin{array}{c}\text { Valencia C } \\
\times \text { ICGV-SM } \\
99566\end{array}$ & $\begin{array}{c}\text { Valencia C } \\
\times \text { ICGV-SM } \\
90704\end{array}$ & $\begin{array}{c}\text { Valencia C } \\
\times \text { ICGV-SM } \\
96801\end{array}$ & $\begin{array}{c}\text { NuMex-M } \\
\times \text { ICGV-SM } \\
99566\end{array}$ & $\begin{array}{c}\text { NuMex-M } \\
\times \text { ICGV-SM } \\
90704\end{array}$ & $\begin{array}{c}\text { NuMex-M } \\
\times \text { ICGV-SM } \\
96801\end{array}$ \\
\hline $\mathrm{P}_{1}(\mathrm{~S})$ & 7.5 & 7.83 & 8.167 & 8.67 & 7.67 & 7.83 \\
$\mathrm{P}_{2}(\mathrm{R})$ & 2.17 & 1.35 & 5.05 & 2.83 & 1.33 & 4.67 \\
$\mathrm{~F}_{1}$ & 1.67 & 1.83 & 1.83 & 2.0 & 1.67 & 1.67 \\
$\mathrm{~F}_{2}$ & 4.67 & 2.3 & 6.0 & 4.3 & 2.73 & 5.0 \\
$\mathrm{BC}_{1} \mathrm{P}_{1}$ & 6.33 & 6.33 & 7.5 & 8.67 & 7.0 & 6.0 \\
$\mathrm{BC}_{1} \mathrm{P}_{2}$ & 2.83 & 3.0 & 5.0 & 1.83 & 2.33 & 1.67 \\
$\mathrm{~F} \mathrm{cal}$ & $12.16^{\star \star}$ & $8.27^{\star *}$ & $5.47^{\star *}$ & $48.1^{\star *}$ & $34.0^{\star *}$ & $59.4^{\star *}$ \\
$\mathrm{MS}$ & 20.2 & 23.2 & 21.1 & 16.1 & 13.3 & 11.8 \\
$\mathrm{CV}(\%)$ & 29.2 & 26.8 & 27.1 & 24.9 & 30.2 & 20.4 \\
\hline
\end{tabular}

$P_{1}(S)=$ Parent 1elite parents, $\left(\right.$ Valencia $C$ and NuMex- $\left.M_{3}\right) P_{2}=P_{2}(R)$ - the donor parents. $F_{1}=1^{\text {st }}$ Filial generation, $F_{2}=2^{\text {nd }}$ Filial generation, $B C_{1} P_{1}=$ Backcross to sucesptibleparent $\left(P_{1}\right)$ and $B C_{1} P_{2}=$ Backcross to resistant parent $\left(P_{2}\right),{ }^{* *}=$ significant at $95 \%$, $\mathrm{CV}=$ Coefficient of variation, Fcal = F-value, MS = Mean sum of square. The Resistance rating scale: 1-3 (highly resistant), 45 slight (Slightly resistant), 6-7 (moderately susceptibly), 8-9 (highly susceptible)

TABLE 2. Genetic variance components and parameters for groundnut rosette resistance

\begin{tabular}{lcccccc}
\hline Generation & $\begin{array}{c}\text { Valencia C } \\
\times \text { ICGV-SM } \\
99566\end{array}$ & $\begin{array}{c}\text { Valencia C } \\
\times \text { ICGV-SM } \\
90704\end{array}$ & $\begin{array}{c}\text { Valencia C } \\
\times \text { ICGV-SM } \\
96801\end{array}$ & $\begin{array}{c}\text { NuMex-M } \\
\times \text { ICGV-SM } \\
99566\end{array}$ & $\begin{array}{c}\text { NuMex-M }_{3} \\
\times \text { ICGV-SM } \\
90704\end{array}$ & $\begin{array}{c}\text { NuMex-M } \\
\times \text { ICGV-SM } \\
96801\end{array}$ \\
\hline$V_{E}$ & 0.83 & 0.90 & 0.90 & 0.70 & 0.60 & 0.50 \\
$V_{G}$ & 1.50 & 1.93 & 1.63 & 1.93 & 1.07 & 1.20 \\
$V_{A}$ & 0.83 & 0.99 & 0.79 & 0.97 & 0.70 & 0.55 \\
$V_{D}$ & 0.67 & 0.94 & 0.82 & 0.99 & 0.37 & 0.65 \\
$V_{P}$ & 2.33 & 2.83 & 2.51 & 2.66 & 1.67 & 1.70 \\
$X$ & 5.30 & 2.40 & 7.00 & 6.80 & 2.20 & 6.40 \\
PCV & 28.80 & 70.10 & 22.60 & 23.60 & 58.00 & 20.40 \\
GCV & 23.10 & 57.80 & 18.10 & 20.50 & 47.10 & 17.10 \\
$h^{2}$ & 64.40 & 68.20 & 64.00 & 73.70 & 64.10 & 70.60 \\
$h^{2}$ & 35.60 & 34.90 & 31.00 & 36.40 & 41.90 & 32.40 \\
GA & 1.12 & 1.20 & 1.02 & 1.23 & 1.10 & 0.86 \\
GAM (\%) & 21 & 50.5 & 14.67 & 18 & 50.7 & 13.5 \\
\hline
\end{tabular}

$V_{E}=$ Environmental variance, $V_{G}=$ Genotypic variance, $V_{A}=$ Additive variance, $V_{D}=$ Dominance variance, $P C V$ and $G C V=$ Phenotypic and Genotypic Coefficient of Variation respectively, $h_{2}{ }^{b}$ and $h_{2}{ }^{n}=$ Broad and narrow sense heritability, respectively, $X$ $=$ Grand mean of the generations, GAM\% = Genetic Advance as percent of mean. 
96801(17.1\%) crosses, which exhibited moderate GCV values. Broad and narrow sense heritability estimates for GRD disease score ranged from 64.1 to $73.7 \%$ and 31 to $41.9 \%$, respectively, in all the crosses. The GAM was high in all the crosses (21-50.7\%), except for Valencia C x ICGV-SM 96801 (14.67), M x ICGV-SM 99566 (18\%) and NuMex$\mathrm{M}_{3}$ x ICGV-SM 96801 (13.5\%) which exhibited moderate GAM.

\section{DISCUSSION}

The six crosses showed highly significant differences $(\mathrm{P}<0.01)$ among generations for GRD resistance (Table 1), suggesting presence of variability for GRD disease score in the generations. The significant variation implies that genetic improvement of groundnut for GRD resistance is possible, and can be exploited by breeders for groundnut improvement. The presence of such variability could be a result of wide genetic distances between the parental backgrounds that were used in the study.

Results of the current study are comparable to those Monyo et al. (2007), who reported variability for GRD resistance among 143 accessions that were evaluated. Naidu et al. (1999) also reported GRD variations to be due to diversity among the causal agents (sat RNA variants), diferences in genotype response, variable climatic conditions and mixed infections with other viruseses. High resistance was exhibited by donor parents, ICGV-SM 99566 and ICGV-SM 90704. Waliyar et al. (2007) and Okello et al. (2010) also reported the two lines as universal donor for GRD resistance.

The mean of $F_{1}$ generations tended towards the mean of resistant parents (Table 1), indicating that resistance to GRD could be controlled by dominant genes or epistatic gene action. These results support earlier reports that resistance to GRD is controlled by dominant genes (Olurunju et al., 1992; Akpan and Olurunju, 2009). Tolin (2012) approximated that over $80 \%$ of known virus resistance was $50 \%$ completely dominant, with the remaining being polygenic,which is comprable to the finds of the current study.In contrast, Harkness (1977) and Nigam and Bock (1990) reported recessive genes controlling resistance to GRD. The presence of dominant genes, implies that the $\mathrm{F}_{1} \mathrm{~s}$ could be utilised due to relative heterosis where hybrid vigour could be exploted. However, in groundnuts, commercial production of $F_{1}$ seed can not be achieved since it is a self-fertilising crop and a tetraploid nature makes the $\mathrm{F}_{1}$ s unstable. Wambi (2014), suggested that in such situations, selection should take place at later generations when the dominance effects of the genes are decreased. To exploit such heterosis, breeding methods such as recurrent seletion and single seed descent may be used.

Success of genetic improvement is attributed to the magnitude and nature of variability present for a specific character (Wambi, 2014). Moderate to high level GCV (17.1-57.8\%) and high PCV (20.4$70.1 \%$ ) were noticed for all crosses (Table 2), indicating higher magnitudes of heritable variations for GRD resistance in these crosses. This could be attributed to genotypes with very little effect of the environment. According to Oyiga and Iguru(2011) and Vishnuvardhan et al. (2012), when the magnitude of genetic variance is higher than the environmental variance, it may indicate a predominance of additive gene actions, which could result to high response to phenotypic selection in early generations due to high influence of the genetic component to the total variance of the trait under study.

Information on genotypic coefficients of variation (Table 2) reveals the existence genetic variability present in the genotypes for GRD resistance, but does not provide full scope to assess the variation that is heritable. In our study, all crosses had high broad sense heritability values (64.1-73.7\%) (Table 2). The findings are comparable with those of several other researchers (Van der Merwe,1998; Adu Dapaah, et al., 2007; Kayondo et al., 2014), who reported high broad sense heritability estimates for GRD resistance (67-93\%). High heritability indicates a high response to selection due to reduced environment influence and predominance role of additive gene effects (Tafere et al., 2013), in the control of GRD resistance, which could result to efficient response to selection in early generations.

However, it should be noted that Broad Sense Heritability coefficients comprise all the genetic influences in its expression, instead of only the additive effects of additive genes. This cannot 
be used as an indicator for obtaining a precise estimation of selection gains. Therefore, $h_{2} \mathrm{n}$ coefficients that comprised only of additive effect of additive genes were computed in our study. Moderate values (31-41.9\%) for narrow sense heritability were observed in all crosses (Table 2 ), indicating greater dominance effects on GRD resistance than the additive.

In all crosses, the dominance variance component $\left(\mathrm{V}_{\mathrm{D}}\right)$ exhibited relatively higher magnitudes, compared with additive component $\left(\mathrm{V}_{\mathrm{A}}\right)$, except for except for NuMex-M $\mathrm{M}_{3}$ ICGMSM 90704 which had a relatively lower magnitude. It is generally verified that an increase in magnitude of $\mathrm{V}_{\mathrm{D}}$ implies a decrease in $h^{2} \mathrm{n}$ in the reference to $F_{2}$ generation. Hence selection of genotypes from initial generations for GRD disease score in these crosses may be difficult due to the higher influence of dominance effects. According to Kormsa-art et al.(2002), selection for such traits controlled by dominance becomes ineffective when carried out in early generations. Therefore, selection based on this trait is more effective when undertaken in subsequent generations of all crosses. In this way, the occurrence of heterozygotes would be reduced and the available additive variance for selection increased, thereby providing higher possibilities of selection gains for the trait.

The genetic advance, as percentage of mean (GAM), was high in all the crosses (21$50.7 \%$ )(Table 2), except for Valencia C x ICGV-SM 96801 (14.67\%), $M_{3} \times$ ICGV-SM 99566 (18\%) and

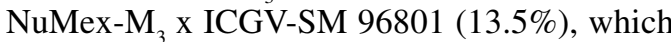
exhibited moderate GAM. According Wambi (2014), high GAM indicates a predominant role of additive gene actions in control of GRD resistance, which is very important for the improvement of a crop through breeding; while moderate GAM reflects additive and non-additive effects in control of the trait under study. Breeding methods such recurrent selection and biparental mating would useful for improvement of such traits controlled by additive and non-additive effects (Nidagundi et al., 2012).

\section{CONCLUSION}

The study has revealed presence of considerable heritable variation for GRD resistance, revealing a greater success of these exotic materials to genetic improvement. Moderate narrow sense heritability (31-41.9\%) was evident in all crosses; however, the heritability estimates depend on the genetic background of the parents that were used. Therefore, selection based on this trait is more effective in subsequent generations in all crosses when the available additive variance for selection is increased, thereby providing higher possibilities of selection gains for the trait. Breeding methods such recurrent selection and biparental mating can be used for improvement of the materials for GRD resistance.

\section{ACKNOWLEDGEMENT}

This study was funded by the United States Agency for International Development (USAID) under the Peanut Collaborative Research Support Program (Peanut CRSP) grant ECG-A-00-07-000100 . We acknowledge the Legume Improvement Programme, National Semi-Arid Resources Research Institute (NaSARRI) of the National Agricultural Research Organisation (NARO), Uganda, for providing germplasm, glasshouse for hybridisation operations and field for evaluation of breeding materials.

\section{REFERENCES}

Adu Dapaah, H.K., Asibuo, J.Y., Danquah, O.A., Asumadu, H., Haleegoah, J. and Asafo, A.B. 2004. Farmer participation in groundnut rosette resistant varietal selection in Ghana. In: Proceedings for the $4^{\text {th }}$ International Crop Science. Congress, Brisbane, Australia. pp. 96:1066-1072

Adu-Dapaah, H.K., Asumadu, H., Lamptey, J.N.L., Haleegoah, J. and Asafo, A. 2007. Farmer participation in groundnut varietal selection. African Crop Science Conference Proceedings 8:1435-1439.

Akpan, G.I. and Olorunju, P.E. 2009. Yield stability and resistance to leaf spot diseases and rosette in groundnut. Czech Journal of Genetics and Plant Breeding 45(1):18-25.

Atta, B.M., Haq, M.A. and Shah, T.M. 2008. Variation and inter-relationships of quantitative traits in chickpea (Cicer 
arietinum L.). Pakistan Journal of Botany. 40: 637-647.

Harkness, C. 1977.The breeding and selection of groundnut varieties for resistance to rosette virus disease in Nigeria. pp. 1-45. In: Submission to the African Groundnut Council, June 1977. Institute for Agricultural Research, Ahmadu Bello University, Zaria, Nigeria.

Janila, J., Nigam, S.N., Manish, K., Pandey, P.N. and Rajeev, K.V. 2013. Groundnut improvement: Use of genetic and genomic tools. Peanut Science 10.3389.

Johnson, H.W., Robinson, H.F. and Comstock, R.E. 1955. Estimates of genetic and environmental variability in soybeans. Agronomy Journal 47: 314-318.

Kaaya, N.A and Warren, H.L. 2005. A review of past and present research on aflatoxin in Uganda. African Journal of Food, Agriculture, Nutrition and Development 5:13.

Kayondo, S.I., Rubaihayo, P.R., Ntare,1.B.R., Gibson, P.T., Edema, R., Ozimati, A. and Okello, D.K.2014. Genetics of resistance to groundnut rosette virus disease. African Crop Science Journal 22:21-29.

Kearsey, J.M. and Pooni, S.H. 1996.The genetic analysis of quantitive Traits. $1^{\text {st }}$ ED. Chapman and Hall, London, UK.

Kormsa-art, T., Jogloy, S., Wongkaew, S. and Lertrat, K. 2002. Heritabilities and correlations for late leafspot resistance and agronomic traits in groundnut (Arachis hypogaea L.). Songklanakarin Journal of Science and Technology 24: 555-560.

Krapovickas, A. and Gregory W.C. 1994. Taxonomy of the genus Arachis (Leguminosae). Bonplandia 8:1-186.

Mark, A., Marsalis, Naveen,P., Natalie, P., Goldberg, J.A., Sanoga, S. and Trostle, C. 2009. New Mexico Peanut Production Circular 645.

Monyo, E.S., Osiru, M.O., Waliyar, F. and Charlie, H. J. 2007. Screening groundnut varieties for resistance to the groundnut rosette disease. International Crops Research Institute for the Semi-Arid Tropics (ICRISAT), Lilongwe, Malawi.
Nidagundi, J.M., Patil, S.S., Salimath, P.M., Kajjidoni, S. J., Patil, B. C. and Hegde, M.G. 2012. Genetic analysis of seed cotton yield and its component traits in Gosspium hirsutum L. Kanataka Journal of Agricultural Science 25: 260-261.

Nigam, S. N. and Bock, K.R. 1990. Inheritance of resistance to groundnut rosette virus in groundnut (Arachis hypogaea L). Annals of applied Biology 117:533-560.

Okello, D.K., Biruma, M. and Deom, C.M. 2010. Overview of groundnuts research in Uganda: Past,present and future. African Journal of Biotechnology 9:6448-6459.

Okello, D.K., Akello, L.B.,Tukamuhabwa, P., Odong, T.L., Ochwo-Ssemakula, M., Adriko, J. and Doem, C.M. 2014. Groundnut Rosette symptoms types distribution and management of the disease in Uganda. African Journal of Plant Science 8:153-163.

Olorunju, P.E., Kuhn, C.W., Demski, J.W., Misari, S.M. and Ansa, O.A. 1992. Inheritance o f resistance in peanut to mixed infection of groundnut rosette virus (GRV) and groundnut rosette assistor virus and single infection of GRV. Plant Disease 76:95-100.

Oyiga, B.C. and Iguru, M.I. 2011. Genetic variation and contributions of same floral traits to pod yield in bambara groundnut (Vigna subterranean L.verdc) under two cropping seasons in the derived Savana of South-East Nigeria. International Journal of Plant Breeding 1:58-63.

Patte, H.E., Isleib, T. G., Gorbert, D.W., Giesbrecht, F. G. and Cui, Z. 2001. Parental selection in breeding for roasted peanut flavor quality. Peanut Science 28:51-58.

Payne, R., Harding, W.S.A., Murray, D.A., Soutar, D.M., Baird, D.B., Glaser, A.I., Channing, I.C., Welham, S.J., Gilmour, A.R., Thompson, R. and Webster, R. 2010. A Guide to ANOVA and Design in GenStat. $13^{\text {th }}$ Edn. VSN International Ltd. pp.1-103.

Singh, R.K. and Chaudhary, B.D. 1985. Biometrical Methods in Quantitative Analysis. Kalayani Publishers. New Delhi, India. p. 318.

Sivasubramanian, S. and Menon, M.1973. Heterosis and inbreeding depression in rice. Madras Agricultural Journal 60: 1139. 
Subrahmanyam, P., Naidu, R.A., Reddy, L.J, Kumar, P.L. and Ferguson, M. 2001. Resistance to groundnut rosette disease in wild Arachis species. Annals of Applied Biology 139: 4550.

Tafere, M.,Tadesse, D. and Yigzaw, D. 2013. Genetic variability, heritability and correlation in some faba bean genotypes (Vicia faba L.) grown in Northwestern Ethiopia. International Journal of Genetics and Molecular Biology 5:8-12.

Tolin, S. 2012. Genetics, genomics and R genes for virus disease management. $7^{\text {th }}$ International IPM Symposium. Virginia Tech. Are ecologically based IPM strategies relevant for sustainable management of virus disease in the 21st Century? March 27-29, 2012, Memphis, Tenessee, USA.

Vishnuvardhan, K.M., Vasanthi, R.P., Reddy, K.H.P. and Reddy, B.V. 2012. Genetic variability studies for yield attributes and resistance to foliar diseases in groundnut (Arachis hypogaea L.). International Journal of Applied Biology and Pharmaceutical Technology 3: 390-394.
Waliyar, F., Kumar, P. L., Ntare, B.R., Monyo, E., Nigam, S.N., Reddy, A.S, Osiru, M. and Diallo, A.T. 2007. A century of research on Groundnut Rosette Disease and its management. Information Bulletin No. 75. Patancheru 502 324, Andhra Pradesh, India. International Crops Research Institute for the Semi-Arid Tropics. 40 pp.

Waliyar, F., Lava, K., Osiru, P.M., Monyo, E., Ntare, B.R. and Nigam, S. N. 1999. Centennial of research on groundnut rosette disease: What is known and what still needs to be known to achieve effective control of this menace in Sub- Saharan Africa. International Crops Research Institute for the Semi-Arid Tropics (ICRISAT), Patancheru 502324 , Andhra Pradesh, India.

Wambi, W., Tukamuhabwa, P., Puppala, N., Okello, S.D.K., Nalugo, R.G. and Kaaya, N.A. 2014. Narrow sense heritability and gene effects for late leaf spot resistance in valencia groundnuts. African Journal of Crop Science 22:327 - 336

Wambi, W. 2014. Inheritance of late leaf spot (Phaeoisariopsis personata) resistance in Valencia groundnuts. MSc. Thesis, Makerere University, Kampala, Uganda. 61pp. 